\title{
AZ MTA VEZETÉS- ÉS \\ SZERVEZÉSTUDOMÁNYI BIZOTTSÁGA EMLÉKÜLÉSE
}

2008. december 10-én az MTA Vezetés- és Szervezéstudományi Bizottsága emlékülést rendezett az egy évvel korábban elhunyt Ladó László, a tudományág egyik nagy egyéniségének tiszteletére. Alábbiakban az ott elhangzottak alapján készített jegyzókönyv szerkesztett változatát közöljük.

Elnöki felvezetés

Dr. Barakonyi Károly, az MTA VSZB elnöke,

a PTE professor

Dr. Barakonyi Káoly, az MTA VSZB elnöke, a PTE professor Emeritusa bevezetójében hangsúlyozta, hogy Ladó

Lászlónak elévülhetetlen érdemei vannak a hányato sorsú hazai vezetés- és szervezéstudomány fejlesztésêben. Képes volt különböző időszakokban, különböz politikai sźljórá mellett is szakmai hitelességével

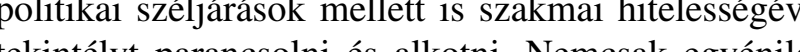

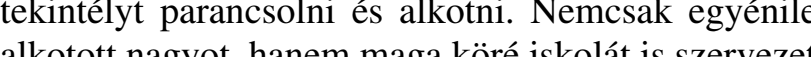
alkotott nagyot, hanem maga kore iskolat is szervezet Sokan sokat koszön 2007 ti. Mindregig aktív, szelemileg friss maradt. 2007 tavaszan egy a tudományterületünk hazai nagyjairól hasonlo MTA VSZB-ülése még ô is előadott (Erdei Ferencról emlékezett meg).

Barakonyi Károly ezután Ladó László közvetle kollégáit kérte fel, hogy tartsák meg megemlékező felszólalásukat.

Aki vállalta $\quad$ Múlik az idó és vele Dr. Kindler József, alábbis ha visszago a BCE Emeritusa szú sorára, melyben egyes kiemelkedố személyiségek meghatározóak voltak, és közülük is elôrelátása és végig kitartó, fáradhatatlan munkássága révén Ladó László tartósan emlékezetes marad. Elgondolkodhatunk hihetetlenül nyugod fegyelmezettségén, pontosságán és azon, hogy hosszu élete során szinte láthatatlanul épült be a szakmai közösségekbe és csak most, egy évvel az evilági életbó való távozása után vehetjük számba hatását.

Jomagam nem tartoztam az 1963-tól nagy gondossággal kiêpített és ôsszetartó tanszéki közösségbe, met szellemesen csípós megjegyzése szerint amolyan „magantudósként" múködtem, ez a tény azonban nem akadályoz meg abban, hogy kijelentsem: Ladó Laci mindig is a szakmai és általános emberi korrektség példájaként áll elốttem - noha 1986-ban egyetemet váltottam - a különféle tudományos fórumokon való találkozásainkon, a korábbi évek alatt is meglévő csendes és mély zzimpátíval viseltettïnk egymás iránt. Hogy ennek mi volt a titka, azt megpróbálom most megfogalmne

Az eszmék, nézetek, beszédek mostani zúrzavar-

(avaránan, kulöösen, ha figyelembe vesszuk egyes nemes g. picin kicsinyes, nézetfeladó ugyködések során elveszti gi, tartalmas, megalkuvásmentes jelentését. Márpeig dr. Ladó ebben az elfeledett ertelemben úriember olt és marad is mindazok szemében, akik ismerhették. Csakhogy miképpen válik azzá? Olyan kérdés ez, amelyre nem egyszerú felelni, és nézetem szerint a neveltetésen kívül az egyéniség a meghatározó, amely egyedi, vagyis Ady költói szavainak értelmében önrendelkezésú, autonóm individuumról van szó: „Sem tódja, sem boldog ôse, sem rokona, sem ismerốse nem vagyok senkinek.

Megtartva az egyéniség „észak-fok, titok, idegenség" másra vissza nem vezethető különleges jellegét a neveltetésben lelhetünk magyarázatot, mégpedig a rendíthetetlenül, talpig becsületes, ludovikás katonatiszt jellemében, aki mélyen, ôszintén - $\mathrm{s}$ tegyük hozzá -, higgadt okossággal látta meg a közösség nagy erejú mivoltát a világégéses háborúban éppen úgy, mint a háború utáni tudományos életében. Mi tagadás, kevesen voltak - s most ne kutassuk a miértet -, akik az 1943as doni háborús pokolból épségben hazahozták a rájuk bízott katonákat, amiért igen magas kitüntetéssel jutalmazták a szó szoros értelmében vitéz főhhadnagyot.
A megfontolt és érett nyugodtság példaképe volt, amely olykor túlzott zárkózottságnak túnhetett, me alighanem senki sem látta önuralma legkisebb elvesz tését sem, noha nyilvánvalóan a zúrzavaros, kemény éveket megélt, hosszú életében lehettek ennek indok és alkalmai.

És most térek ki arra a hallatlanul okos váltásra, am nemcsak Lacinak, de más ludovikás tiszteknek is - ha nem is mindegyiknek - a szó igazi értelmében vett hazafias tett volt. Elsősorban hazafiak voltak, mert ittho maradtak, noha Nyugatra távozva élhettek volna zavarmaradté, nz itthon ták na emesebb része vállar talan éle no Ny a fáradtságos ujnakezdés sorsut, amelynek koromn fogva tanuja lehettem. Már 1948-ban - első éves vegyészmérnok-hallgatókent - feltûnt, hogy az akko évfolyamtársak kozoott volt nehanny csendes, hallatlan szorgalmas, jól tanuló, idósebb kollégám, akikról késốbb kiderült, hogy 1945-ig ludovikás katonatisztkén szolgáltak. Tudomásom szerint múltjukból a késóbbiek során sem lett semmiféle bajuk - köszönhető ez kiválo készségeiknek -, és többen közülük vezetố beosztásban ténykedtek nyugdíjazásukig. Késốbb, a másoddiplomáért tanuló gazdasági mérnök, felnőtt tanulók közö is voltak feltűnően szorgalmas, jó képességú jelöltek, akik közül az egyik szálas tartású, és egyetemi doktori fokozatot szerzô, általam is támogatott, kiemi doktori fokozatot szerzo, altalam is tamogatott, kiemelked hallgatóról csak hosszú évek múlva - mintegy véle

Szó a kzo Ladó

Szó ami szó Ladó László, a korabi tủzertiszt már a sorsfordito 1945-0̈s háborús zaráskor felismerte, hogy „tempora mutantur" - azaz - valltoznak az idő́k, és „e nos mutabinur in ins" - vagyis -, mi is valtozunk idővel. E meglátás alapjann már 1948-ban a közgazdaságtudományok egyetemi doktora lett, azaz - megítelésem szerint - elsốként ismerte fel a nélkülözhetetle szakmaváltás szükségességét. Az ezt követő életútjât jól tükrözi a „Vezetéstudomány” 2008. áprilisi szamában a vezetés-szervezés diszciplína nagyjairól és esetében róla szóló, Erdősi Gyula által írott tartalma megemlékezés. Elolvasva a hiteles munkatársa álta rótt megemlékezést, be kell látni, hogy Ladó Lászlo mét megelôzte korá, wagyis a nâr entitett nyugalmáv

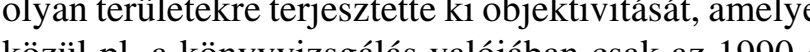
kózul pl. a könyvizsgálás vajujban csak az 1990-es váltás után került az érdeklődés meghatározó homlok-

1979-tól 1984-ig a Múegyetem Ipari Üzemgazd ságtan Tanszékének vezetóje volt, tehát magam is közvetlenül megtapasztalhattam bölcs, csöndes, de azét szerfelett eredményes, meghatározó munkásságát. A k váló munkahelyi légkör megteremtésének egyik emlékezetes eseményeként kiemelem a szükségképpeni sebb, belsố ellentéteket elsimító, egyik tavaszi, tanszéki áncos, hangulatos délutánt, valamikor a 80-as évek elejen, amely nemcsak nekem, hanem valamennyi akkori résztvevőnek a legüdítóbb, legkellemesebb élményei közé tartozik, s ahol Ladó Lászlóban felcsillant a hangulatteremtés varázsa és a megteremtődött békesség.

Késóbb, az 1990 utáni, esetenkénti, olykor véletlen találkozásainkkor megszabadulván az addig csak elleplezett szózár kötöttségeitól, a csillogó szemével és személyiségével összhangot teremtô, szerény, de változatlanul nagyon okos és szellemes megnyilvánuván már az igen szép alkonyt vetítették elôre. Mégis

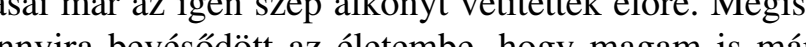

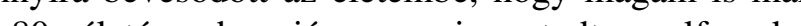
a La Laci csak eltávozott, dimenziót váltott és most az égiennek tart kifogástalan csiszoltsággal - mint arbite elegantiarum, az elegancia mestere - szellemdús elố-

Vitéz Ladó László professzor, Ladó Laci, találkozunk még a békességes túlvilágon! Addig is: Isten veled!

\section{Az MSZI mint} lius Caesart, a római demokraták által bruDr. Magyari Beck István, tálisan (e szó feltea BCE professor tân Emeritusa szervezkedés vezetốjének a nevéből eredt) meggyilkolt római diktátort búcsúztatta, az alábbi szavakkal indította nekrológját és ordította ezzel a demokrata párti tömeg Caesar-ellenes angulatát annak ellenkezójébe, az áldozat irányába: „Temetni jöttem Caesart, nem dicsérni”. Legalábbis ez történt Shakespeare nevezetes drámájában. Nos, elő́ttem egészen más feladatok állnak. Egy a keletkezésének korában bár támadott, végül mégis elfogadott és a jelen viszonyok közepette is elóremutató Magyar Szervezéstudományi Iskolát - amelyet voltam bátor MSZInek elnevezni abban a reményben, hogy e rövidítésre jövő́ben nagy szïkség lehet mert - reményeim szerint újrálesztiik śs sikeres folytatáśń döntiink ma itt,

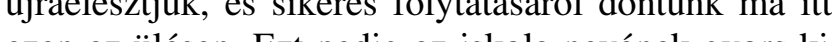

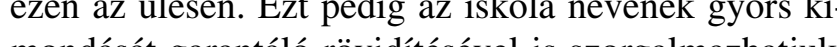
Ezćt bat garantáló pơvidítésével is szorgalmazhatjuk. Ezert bever megfordításával. Jelesül: „Dicsérni jöttem a Magyar Szervezéstudományi Iskolát, és nem temetni.” Teszem ezt mindenekelótt azzal, hogy az MSZI-t - amelynek az iskolateremtó Ladó László egyik vezéralakja volt a Magyary Zoltán-tanitvány Szabó Lászlóval és a miskolci professzor Susánszky Jánossal együtt - kiragadom a szúkebb magyar kontextusból és nemzetközi jelentôségét hangsúlyozandó, nemzetközi perspektí- 
vában vizsgálom meg. Az elsố tételem e tárgyban az, miszerint az MSZI nem volt semmilyen irányból sem epigon. Sem a keleti, sem a nyugati iskolákat nem masolta. Igazi közép-európai termék volt, amely önállóságában is képesnek bizonyult a keleti egyoldalúságok a nyugati értékekkel orvosolni és - más oldalt - a nyugati szellem túlbuzgó dinamizmusát keleti megfontoltsággal és hagyományszeretettel tartani egyensúlyban. De úgy, hogy mindeme teljesítményei nem írhatók akként, mintha az iskola egyfajta tudományos hint politikát valósított volna meg. Igazi önálló koncepció politikát valosítot volna meg. Igazi onnáló koncepció és geopolitikai elemeket. Hogyan tette ezt? Amit az alábbiakban készülök
Hogno elóadni, további kutatásokat kíván. Azaz a mondanivalóm nem tart igenyt végleges es szakmai disputát nem tứró igazságokra. Viszont fol kivanom vetni az Iskola eredetiségének és gyökereinek a kérdését, de - mint fönt említettem - nem csupán kutatási célokból, hanem az iskola elméleti és gyakorlati folytatásána céljából a megújult, de változatlanul nehéz, sốt súlyosnak mondható történelmi körülményeink közepette. Ugyanis, globalizáció ide, globalizáció oda, lokális helyi adottságok kemény tények, amelyeket a mindenkori siker érdekében nem szabad figyelmen kívül hagyni. Mindenekelôtt az iskola szemlélete utókivül hagy. Ming szemlelete utópista volt. Vagy - Max Webenrel szólva - normatív piscallpur. fogásból kiindulva, hogy e modellek egy az egyben, azaz változtatások nelkul alkalmazhatoak lesznek. Alkalmazásuk a valóság olyan szándékos provokációja volt, amely logikusan vezetett „a szín és a való” k lönbségét megvilágító problémák generálásá hoz. Ez pedig az - ismétlem: szándékosan - utópista modellek korrekciojához. Az utóbb Nobel-díjat kapott - és akkor már az Egyesül Államokban élô - Harsányi Jáno - aki különben az iskola személyes kapcsolatainak révén az MSZI kültagja is volt - mondotta el egyik, nekünk adott interjújában, hogy ilyen metodológiai éttelme van az emberi racionalitás megkövetelésének közgazdaságban is. Ugyanis a tökéletes gazdasági racionalitás feltételezése az embereknél rendre ugyanezen racionalitásra vonatkozó kutatások eredményeinek és az ezeken alapuló gazdasági gyakorlatnak a módosítására és árnyalására vezetnek (Magyari Beck, 1989). Minden ideáltípus közös sorsa ez, amikor az empíri val találkozik. Viszont ideáltípusok nélkül nem hala hat elöre - mi több, fönn sem maradhat - az emberiség. Nota bene, a szocializmus látványos és gyors összeonlása nagyon sokat köszönhet Marx és követối utópis szocializmus iránt táplált engesztelhetetlen gyúlöletének. Ezért aztán a kommunista forradalmárok sem- miféle elképzeléssel nem rendelkeztek arról, hogy mi történjen egy gyôzztes forradalom után. Che Guevara tragikus sorsa is a Kubában győztes szocializmus remenytelen hétköznapjaitôl való halálba meneküléskén értelmezhetó a mind stratégiailag, mind taktikailag képtelen utolsó bolíviai vállalkozásai révén (Moldova György, 2005). Tudniillik ezek a „megváltók” nem jutottak tovább a maradéktalan államosítás végleteinél. Szemben a piacgazdaság és a klasszikus liberalizmus olyan teoretikusaival, mint Smith, Bentham, James és John Stuart Mill, és ́gy tovább, akik sorra dolgozták és polgári utópiáikat amin azután bőven volt és van is mit javítani a bevezetésük után.

Mármost a normák univerzumában mindig bizonyos szabadsággal mozog az emberi értelem. Ha azonban valaki - miként Szabó László - a szervezetról, mint Z emberi együttlét optimumáról beszél (Szabó László, 1967), akkor abban benne kell, hogy legyen - mint hogy benne is volt és van explicite is az MSZI keretein belül készült anyagokban (1. Ladó László, 1986) mind a szakmaiság, mind a gazdaságosság, mind a pszichológiai klíma, mind a korszerúség, mind az individualitás megbecsülése, mind a kooperációra való hajlam és képesség, mind a jövedelmezőség, mind a versenyképesség, mind a tárgyi rend, mind az adminisztratív ésszerúsés mind a munkentyin az admimind esszerúség, mind a munkahelyi demokrácia

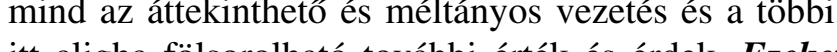
az erenyeke nen lehe agy osze az erényeket nem lehet úgy összefoglalni, ahogy ezt a mai szervezetek - éppen a legfejlettebbek kezdeményezesere úgyszolván vilagszerte - a monetáris bevételek maximalizalásara egyszerüsitik, a többi eszme és tárgyi érték, érdek és elöny rovására. Korunk egyik képtelensége az egydimenziós szervezet ,föltalálása" (vagy inkább eróltetése), ami mögött egy hibás pénzelmélet áll. Jelesül az, hogy a pénz már most minden érték kifejezésére alkalmas csodaszer. Azt is mondhatnám, hogy ez a banki modell monopóliuma. Csak azért nem mondom mert még a bank sem tudna túlélni a monetáris picon, ha nem tenne eleget példá

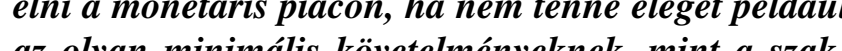

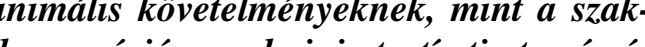
szen tose a kooperacio, az. adminisztrativ tisztesség és gy toubb, ani viszont azind pénzbe kenl, tehát csökkenti a banki bevételek netto összegét. Viszont éppene csokkentés altal teszi oket lehetove. Aki zérusból kiván új számot elóallitani, az képzelheti ugyan mágusnak magát, de a semmibốl ó is csak a semmit állithatja eló. A közgazdaságtudomány az tudomány és nem mítosz. Más szavakkal, még az a pénzautomata sem sikeres, amely csak pénzautomata. Még a legegyszerúbb esetekben sem. Ugyanis, ha akárcsak a meróben technikai pénzautomatáról beszélünk, minimálisan a technikai és a bünözéssel szembeni biztonságnak is megoldottnak kell lennie. Hát még ha a munkaszervezetból kísérelnek meg pénzautomatát kreálni! Az MSZI inputoutputszemlélete a mondottak szerint ma is megállja a helyét, és mindaz, ami e téren azóta is történt, lehet bár innováció, sốt technikai tökéletesítés, de eszmeile nem haladás, hanem inkább visszaesés.

Az MSZI sokoldalúságra és - a maximum helyet - a józan és komplex optimumra való törekvése mellett volt ennek az iskolának egy módfelett lényeges valóban minden idókre és helyzetre szóló mentaitóstörténeti üzenete. Ez pedig az emberi szabadságnak mint alapvetótodottságnak-állandó jelenléte minden még a legkegyetlenebb körülmények között is. Ebbó még a legkegyetlenebb körülmények között is. Ebbón meg erkölcsi szempontból a kezdeményezés és a javít szándék kötelezettségei vezethetóek le, bármilyenek legyenek a társadalmi és a természeti feltételek. Nehéz volna azt allítani, hogy az MSZI születése a magyar történelem legborzalmasabb korára esett. Tudun e kornál sokkalta súlyosabb idókról is beszámoln A viszonylag rövid történelmi távolság még nem engedélyezi teljességgel a szóban forgó korra vonatkozó elfogulatlan nézetek és vélemények érvényesülését (nem a Rákosi-korról beszélek). Egy körülmény azonb kétségtelen. Az 1960-as évek - körülbelül ebben a periódusban keresendó az iskola szïletéśnek pon a penótuma -, nos, ezek az évek is még egy neglosabb dátuma -, nos, ezek az evvek is nilg egy meglehetósen merev program jegyében zajlottak. Ezt a programot súlyos buntetések terhe mellett el kellett fogadni, minden onmagának és a tényeknek ellentmondó tételei és ins rukciói ellenére. Fơkéntideológiai szempontból. Péld ul, azóta sem vált világossá, miként lehetett egyszerre ortodox marxistának lenni és mégis napirenden tartani, sôt széles körben gyakorolni a Marx által elátkozo cserét, voltaképpen minden gazdaság alapját? Vagy hogyan lehetett az értelmiséget rendre utolsónak említen és hátrányos helyzetbe hozni a dolgozó rétegek között, amikor az értelmiség politikai szempontból teljese megfelelt a marxi munkásosztály definíciójának, lévén nem rendelkezett a termelószközök kizskn nem rendelkezett a ten szolgalo to tervgazdálkodásnak tekinti magát, amely értelmiség tervezók nélkül elképzelhetetlen. Az eszmei kuszaság tervező́k nélkül elképzelhetetlen. Az eszmei kuszaság ki is termelte a maga savanyú gyümölcsét, melyben hátrányos helyzetú értelmiséget az akkoriban még mértékadó marxista szociologusok a szóban forgó korsz uralkodó osztályává nevezték ki, ami kiáltó ellentétben állt e réteg általános állapotával. Igaz ugyan, hogy - mint utóbb kiderült - a szocializmus ötéves terve sokkal rövidebb periódusokra vonatkoztak, mint egy valamirevaló kapitalista nagyvállalat évszázadokra ké- szített és az egész világra globalizációt ítélő stratégiai elképzelései. A merev program tehát egyebek között abból allt, miszerint ne keressünk koherenciát a fönt mlített ellentmondások között, mert az destrukció.

Ebben a nem éppen biztató intellektuális közegben az MSZI - élve tagjainak a szabad döntések minden lehetőségét megragadó mentalitásával - megalkotta azon flexibilis szervezetek képeit, amelyek a korabeli társadalomban - az alapító atyák (Marx és követói) szélsôségesen kritikai beállítottsága miatt - nem szïlethettek meg. Természetesen nem arról volt szó, giájához elJüjienok létre. Lesen illeszkedó gazdasági egységek jojject szelemében épült társadalmi organizmusok kiépítése ke-

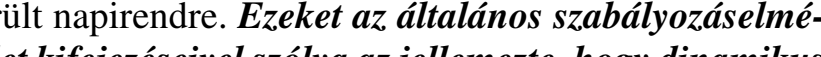
let kifejezéseivel szólva az jellemezte, hogy dinamikus egyensúlyba hozzák és tartják a stabilizáló és a dinamizáló - azaz az állami vagy állami (közigazgatási) jellegü és a gazdasági haszon növelésére irányuló - alrendszereket. Mégpedig minden esetben a reális igényeknek és lehetöségeknek megfelelóen. Ilyenformán a probléma alapvetôen szabályozáselmélet volt. Tehát az MSZI múködése túlmutatott mind a manchesteri szellem irányába húzó kapitalizmuson, mind pedig a kom in unabus idealizalt sźlsmuson,

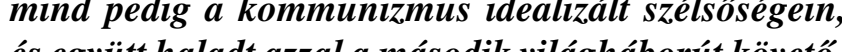
en en már megerosodott kozjelfogással, amely mindenféle külön ideológiai vagy más jellegú fegyver nélkül egyszerre tartotta napirenden a fejlodést és a stabilitast. Es egyiket sem az eroszak, hanem a problémamegoldás alkalmazásának útján (v. ö. az erőszakkal fönntartott, sikerületlen szociáldemokráciát, amelyet fasizmusnak hívunk (Türk Attila, 2008), vagy akár a manchesterí, akár a kommunista végletet, amelyek szintén állig fegyverben óvják magukat). Empirikusan csak az emberi szabadságot meghagyó és arra épító problémamegoldás bizonyul produktívnak, társadalmilag kívánatosnak és tartósnak Néhány évtizede még a legro majd azzón ân egyszer sź́t célkeresztjébe. Ha az MSZI belsó légkörét viz krílika és az ál faḱ és az abból fakadó mentalitástörténeti üzeneteket sorra „levesszúk”, akkor a kutatás és a gyakorlati munka produktivitásának és kivitelezhetốségének ugyanazt a komplexitását találjuk, ami számunkra akkor természetes volt. A komplexitás széles körökben elfogadott belsố ellentmondásosságot - pluralizmust - is jelent, ahogy - más oldalt - az eróltetett koherencia intellektuális és gyakorlati primitivizmust takarhat, ahol az intellektuális primitivizmus az intelligencia maszkjá- 
ba bújik, a gyakorlati primitivizmus pedig a határozot és eltökélt aktivizmus álruhájában kínálgatja önmagát. Ez az üzenet máig is érvényes. Ma is koherens és hat rozottan eltökélt programok nevében dolgoznak társadalmi intézményeink. Csakhogy ezúttal a manchester véglet irányába mutat a hajó orra. Ami azt a feladatot rója ránk, hogy ismét megkeressük és tágítsuk azt a is garantálható

\section{Hivatkozások}

Ladó László (1986): Szervezéselmélet és -módszertan. Közgazdasági és Jogi Könyvkiadó, Budapes

Magyari Beck István (1989): Számúzött értékeink. Akadémiai Kiadó, Budapest. L. „Harsányi János matematika közgazdász" címú részt, 21-46. old.

Moldova György (2005): A napló. Urbis Könyvkiadó, Budapest

Szabó László (1967): Szervezés és vezetés. C. OVF Kiadványból, Budapest

Türk Attila (2008): Mi a fasizmus? Anno Kiadó, Debrecen. Bár Türk Attila a fasizmust inkább a krónikás, semmint a társadalomelmélet szemszögéból mutatja be, gazdag tényanyaga alátámasztani látszik a jelen tanulmány szerzójének azt a fasizmusdefinícióját, miszerint a fasizmus a sikerületlen vagy szándékosan elrontott szociáldemokrácia, amely a vagy spontán, vagy szándékolt és tervezett megoldatlanságait erószakkal próbálja meg kezelni. Azaz, a fasizmus elsősorban a társadalomirányittá si technikék - és azokon belïl is - az erốszak kérdés. Nem pedig önálló rendszerfajta vagy rendszertípus.

Ladó László professzor úr 30 évre látott elốre

Dr. Nahlik Gábor,

a VE tans Gábor, aE tanszékvezeto

Kell néhány szóval indokolnunk azt, am ma valamennyiün számára igaz, ámde hogy miért igaz, az szigorúan tudomá

nyosan kell igazolnunk, ugyanazzal a kérlelhetetle szigorral, amelyet Ô alkalmazott kutatómunkájában és publikációiban.

30-40 évvel ezelôtt, amikor a magyar szervezéstudományi iskolák alakultak, a felsőoktatási intézmétudományi iskolák alakultak, a felsóoktatási intézményekben a szakma múveló gyakran talâlkoztak. A fítal
atalok példamutató igényességet tanulhattak, egyúttal példamutató összetartást is. Ezért a szakma nem vált példamutató összetartást is. Ezért a szakma nem vált men, a Közgazdaságtudományi Egyetemen, a Miskoci Egyetemen, a Veszprémi Egyetemen, a Pénzügyi és Számviteli Fóiskolán, a Szervezési és Vezetési Tudományos Társaságban, a Magyar Tudományos Akadémián, az ipari tárcák tanácsadó és továbbképző inté- zetében intézményenként egy vagy több szervezés- és vezetéstudományi múhely jött létre, amelyek országos ma is a példamutató együttmúködés jellemző.

Amikor a 60-as, 70-es, 80-as évek eredményeiról beszélünk, akkor egyúttal egy szakma felvirágozásáról, hatásának elemzésétốl sem tekinthetünk el. A cím szerinti témához ragaszkodva is el kell mondani, hogy a 70-es évek Budapesti Múszaki Egyetemén, az Ipari Üzemgazdaságtan Tanszéken több nagy egyéniség tanított, kutatott, alkotott. Közïlïk ma dr. Ladó László nított, kutáot, alkót. Kózúlúk ma dr. La

A sok eredmény, publikáció, téma felsorolásával abba a hibába esnénk, hogy sokat markolunk, ámde keveset fogunk. Ezért, talán önkényesnek is tűnő́en néhány elemet ragadnék ki azért, hogy ezeken keresztül világítsuk meg professzorunk munkásságának máig ható eredményeit.

Ezek a következók:

a termelési rendszer szak, a szervezố vegyész szak és a szervezó villamosmérnök szakok létrehozása,

- a gazdasági mérnök szak reformjának megtervezése és bevezetése,

- a rendszerszemléletứ költség- és nyereségfedezeti számítás, az ÁKFN struktúra,

- szervezéselmélet és módszertan, a vezetés szerve-

zési funkciója, egészlátás, komplex közelítésmód.

\section{A termelési rendszer szak kifejlesztése}

Ladó professzor úr, aki a német és angol nyelvú szakirodalmat nagyon szorosan követte, felfedezet egy új szakot. Ezen 1/3 gazdasági, 1/3 múszaki, 1/3 szervezési és vezetési tartalmú tantárgyat hallgattak a hallgatók. Ez volt az industrial engineering szak. A nagyobb nyugati egyetemeken industrial engineering karok is találhatók. Az itt végző́k lesznek világszerte az ipar kapitányai. Párt- és kormányszervek munkatársa vettek részt a cél érdekében létrehozott bizottság munkájában. Ez a bizottsá havonta ülésezett. Az elóterkesztés. jesźesek alapos lektorálás után jutottak el a tagokhoz. Tájékoztatásul, az ülések után, még sok példányt szétküldtünk. Ezt a munkamenetet ma idegen szóval lobbyzásnak, az átláthatóságát transzparenciának hívják. Enélkül ma sem lehet országosan számottevő ügyben eredményt elérni.

A termelési rendszer szak a gépészmérnöki karokon, a szervező vegyész képzés a vegyészmérnöki karokon, a villamos szervezổ mérnök képzés az azonos nevú karon 1972-74. években indult meg. A vidéki egyetemek cselekedtek gyorsabban. Az industrial engineering tí- pusú képzést ma a múszaki menedzser szakokon foly tatják. Emellett a mérnök szakok vezetôi mindig igénylik gazdasági, szervezési, vezetési témájú tantárgya szerepeltetését a tantervben.

\section{A gazdasági mérnök szak reformja}

A gazdaságimérnök-képzés az ötvenes évek végén indult meg, törvényerejú rendelet alapján. A képzést karonkénti bontásban szervezték meg. Az első két félév közös volt mindenki számára. Egy bürokratikus beiskolázási rendszer nem biztosította a versenyképességet. A közgazdaság-tudományi karokon beindult a mérnö közgazdász képzés, hasonló tartalommal közvetlenil lehetett jelentkezni. Ugyanakkor a vállalatoknak nagy szükségük volt a gazdasági, szervezési-vezetési tudással rendelkezó mérnökökre.

Ladó professzor úr nem szorgalmazta a gazdaságmérnök-képzést szabályozó rendelet eltörlését. Csupá a felvételi procedúra leegyszerúsítését oldotta meg jogszabály módosításával. Ezt összekötötte a gazdaságimérnök-képzés 1980 -as reformjával.

Megszúnt az elágazások, ágazatok karokhoz rendelése. Létrejöttek az új elágazások: munkatudományi, kereskedelmi, termelési stb. Ezek az elágazások a ma gazdálkodás és menedzsment BA szakokkal, a múszaki menedzser apszakkal a posztoradúlis MBA szakokla kal tartalmilag erôs átecésben vannak. Mivel a képzés megujjitása elsôsorban a vállalatok versenyképesség nek biztosításaért tơrtent, megállja a helyét az a me állapítás, hogy a gazdaságimérnök-képzés 1980-81-es reformja azon tantárgyak kifejlesztését eredményezte, amelyek már kinőtték egy-két tanszék kereteit a mé nöki karokon. A reform tudományos véghezviteléve vált kétségtelenné az, hogy a múszaki egyetemeken és a tudományegyetemeken indokolt gazdaságtudományi karok létrehozása.

Ma ezek a karok a felsőoktatásban példamutatóan sikeresek. A végzősök álláslehetőségei jók. A képzés tartalmi fejlesztése a termelési rendszer szakok, a gazdasági mérnökképzés reformjával indult meg. A céletérés folyamat́́n java Ladó professzor úr vez. A célé érés folyamatának java Ladó professzor úr vezetéséve valósult meg. A szerveztek, az uj karok, az érdekek és lehetôségek oosszhangja menten intézményenké kulônbözô módon, de vissza mén ki, ma is jól múködnek. Jövő́képük biztos alap a fejlodésükhöz.

A rendszerszemléletú költség- és nyereségfedeze számítás, ÁKFN struktúra költség- és nyereségfedeze számítás mind a tervezésben, mind az ellenőrzésben költségeknek a termelés mennyiségére és a terméköszszetételre való reagálás szempontjából pontos meghatározására épül. A költségek reagálása a technológia és a termék mélyreható ismerete nélkül nem határozható meg. Ezért a költség- és nyereségfedezeti számítás csakinterdiszciplináris közelítésmódban értelmezhetô.

Ladó professzor úr az egységnyi termékre jutó proporcionális költség és a realizálási fedezet bevezetésével olyan új fogalmakat alkotott, amelyek segítségével az ÁKFN struktúra volumen- és termékszerkezet-függơ meghatározása pontossá tehetô. Ezzel nemcsak a nyereségtervezés, hanem a controlling adatbázisát is tartalmilag pontosan meghatározta.

A controllingban alkalmazott standard költségszámítás alapja a pontos tervezés. Mivel azonban a tervezett termelés és a tényleges termelés csak véletlenül lehet azonos, ezért be kellett vezetni a tényleges termelés tervezett költsééének fogalmát, amely már öszszevethető a tényleges termelés tényleges költségével. A Teljesítmények és ráfordítások címú könyvben ez a gondolatmenet a vállalati megvalósítás, bevezetés igényességével található meg. A modern controllingban az uzemvezetés, az egyes részlegek munkájának igazságos értékelési alapja a költség- és nyereségfedezeti számítás. A gondolat részletes kifejtését számos konkrét esettanulmány támasztja alá.

Az új gazdasági mechanizmus hajnalán számosan javasolták a veszteséges vállalatok megszüntetését, amivel elvben ma is egyet lehet érteni. Azonon nem min egy, hogy egy veszteśces vállazonJán besźllíoja van. A motorvonatot elóllít GanzMávagna sok beszállítója volt. A Ladó prónesz

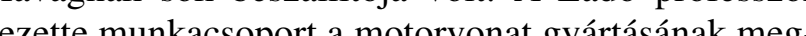
szüntetése előtt először megvizsgélta a ának megmint termék realizálási fedezetét. Kiderült, hogy ez pozitív rám realizálási fedezetét. Kíderuilt, hogy ez atározták mezután a beszálítók AKFN-struktúráit volt. Elkészítették a beszállítók és a motorvonat gyáregység összevont AKFN-struktúráját. Kibontakozott egy nyereséges vállalkozás víziója. Kiderült, hogy a beszállítók által befizetett adó többszöröse a GanzMávag által igényelt dotációnak. A gyártás leállítása elyett megindult a reorganizációs terv elkészítése. Ennek egyik legszebb fejezete volt a motorvonat funkcióelemzése, értékelemzése.

A reorganizáció olyan jól sikerült, hogy még a kincvenes években is gyártottak motorvonatot a privatizáció utáni utódvállalatnál. Mi sem természetesebb, hogy a fốkonstruktốr termelésirendszer-szakos gépészmérnök volt

A vázolt jó példa tömeges követését ma szerte a világon a klaszterek létrehozásától várják. Az értéklánc mentén szerveződő klaszterek kialakításának logikája éppen az, hogy a végtermék-kibocsátó és beszállítók harmóniáját a változó gazdasági környezetben fenn- 
tartsák. Ezért ma is jó szívvel ajánlható a klasztere menedzsmentjének figyelmébe az igazságos osztozkodás érdekében az AKFN-struktúrák elkészítése és nyil kártyaként való alkalmazása az egzisztenciális tétre menő, közös tervezésben.

Egészlátás, komplex közelitésmód

A rendszerelmélet múvelối nagy hatással voltak Ladó professzor úr gondolkodására. Nem riadt viszsza a bonyolultságtól, amikor saját munkájában kreatívan és elegánsan alkalmazni kezdte a rendszerelméle van és elegánan alkalnazni kezdte a rendszerelméle kutatók módszécit, enchéneit. Abból a rendszerelméleti tézisbôl indult ki, hogy egy vállalati ren

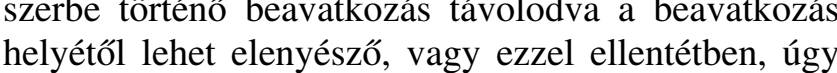
helyetôl lehet elenyeszó, vagy ezzel ellentétben, úgy tovagyúrúzó, hogy a kimenetre gyakorolt hatása fe erősödik. Mivel azonban a vallalati rendszerek anatomiai szempontból nem ismertek kellő részletességgel ezért egy rendszerbeavatkozás hatása formális logik úton, képletszerúen leegyszerúsítve nem számítható ki. Ebbő́l következően a beavatkozás hatásterületeinek feltérképezése szellemi alkotómunka. Azonban ez szellemi alkotómunka a probléma összetettsége mia multidiszciplináris.

Multidiszciplináris képzettségú polihisztorok hiányában a csoportos szellemi alkotó technikák jüheányában a csopotóma megoldás nek szóba a proble szasta ta az vol, hogy a múszaki, szervezeti fejlesztést mi tési terv ismeretében a hatásterületek feltárását végezze szakmailag vegyes összetetelú munkacsoport. A javasolt munkamódszer kézenfekvő́n a 60-as évek végén a brainstorming volt. Ezért ezt a módszert Ladó professzor úr nagyon alaposan megismerte. Volt bátorság a vállalati fejlesztések hatásterületének feltárásakor az alkalmazására.

$\mathrm{Az}$ adatfeldolgozó gépek és rendszerek tantárgy oktatásakor a gazdaságimérnök-képzésben mindig levezetett egy brainstromingot. A hallgatók többsége ekkor találkozott elôször ezzel a módszerrel. A szigorú szaktalâlkozout elószós ebben az esetben is megérlelte gyümölcsét. szuneg ebben azze gyümölcsét. enni. A bllo lenni. A hallgatoság tobbsége lelkesedett. Diplomate vekben gyakran alkalmazták a módszert. Miniszterek, vâllalatvezetók kértek minket ezután moderátori feladatra. Mikor a nominál csoportok módszere (NCM), 635, Philips 66, Delphi, az innográf, a funkcióelemzé ismertté váltak, igény támadt egy csoportos szellemi alkotótechnikák könyv megírására.

Ladó professzor úr ezt tanítványaira bízta. A köny két hónap alatt elfogyott. Irtunk ezért ezután jegyzetet. Ezek tartalma a törzsanyag részben ma is megtalálható

az MBA, az üzleti ág BA szakjain, a múszaki menezser alapszakon.

Mi a közös a néhány címszó alatti gondolatmenetekben? Ladó professzor úrra jellemzó volt a valóság pontos ismerete, a cél meghatározása, a módszer, nyugodtan mondhatjuk, mint termék részletes kidolgozása; a bátor, ámde kárt sosem okozó kísérletezés a módszer bevezetésére, a módszer esetpéldákon keresztül való bemutatása, a módszer publikálása, a módszer tanításának didaktikai megtervezése és realizálása. Az ipar szervezetek, vállalatok komplex, egészlátó fejlesztéséról bebizonyitotta hogy multiszciplin ejeszeté s copolozozható

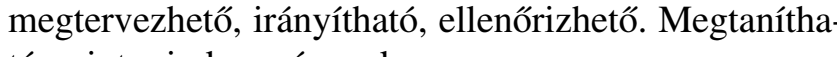
Alk

Alkotó szellemi munkatartalma megélhetés és sikerélmény a múvelói számára. Munkatársai nagyon szerencsések voltak. A munkából ki sem látszottunk. Egzisztenciális biztonságban alkothattunk. Kedvvel dolgozhattunk. Professzorunk képes volt saját definícióját a vezetésról a közvetlen környezetével elhitetni, mert mi magunk voltunk a kontrollcsoport. Ez a definíció: „A vezetés értelmes célok érdekében együttmúködố emberek kedvvel dolgoztatása."

A meghatározás többtényezős célfüggvény alkalmazását teszi lehetốvé Természetesen vállalatok esetében az egyik cél lehet a nyereség optimaliźlás. Azonban a munka terméckenysége a motiváció, a csoportos munkavégzés, az érdekek felismerése és tisztepos numsa a muna ú portok egyiittmúködésének hossú távú a vâlaatcsoigazśgos igazságos teljesítményértékelês, a vagyongazdálkodás ebbe a Ladó professzor úr által megadott definícióba minden erőltetés nélkül beleérthetố. Mondhatjuk, hogy idôtálló, divatoktól mentes az archaikus múltban is és a távoli jövő́ben is jól megállja a helyét.

A nagy lehetôség

Dr. Szórád József, a NYME c. egyetem tanár lan módon egy kiváló oktató, dr. Ladó László professzor úr eászkére gyúltionk össze. Nem tehetjiik egy ne tegyünk említést a gazdasági, pénzüigyi válság történéseiról, amelyek különösen aktuálissá teszik, az ún. valóban hozzáadott érték fogalmát.

A Budapesti Múszaki Egyetem Gépészmérnöki Karának hallgatójaként, kollégáimmal együtt nagy érdeklódéssel fedeztük fel a termelési rendszer szakon történő tanulmányok lehetôségét. A természetesen mindig egzakt múszaki környezetbe kiváló érzékkel illeszkedtek a szervezéstudományi ismeretek. kínált:

Dr. Ladó László professzor úr egy új lehetőséget

- az eladó - marketing szemléletú szervezố mérnök pozícióját.

Alkalmazza múszaki tudását, ismereteit, de egyidejûleg illessze azokat be a folyamatokba, a szervezetbe, és értékesítse, azaz adja el.

Bizonyára sokan emlékeznek az akkori gyakorlara, amikor is a külföldi tárgyalásra hazai színekbe minimum ketten, ha nem többen utaztak. A mérnok és természetesen a kiulkereskedó, aki ha nem is ért a es terti a nem is erti múszaki folyanato a próbálta a prós Ez a szenlelet akko meg nagyon újnak, de néha bizony elutasittotnak számított. A mérnök maradjo mérnök, a külkereskedó kereskedón. Így ültek az egy külföldivel szemben. A professzor úr és munkatárs által oktatottak egy szervezett, racionális rendszer kereteit próbálták kialakítani, minket erre az új szemléletre nevelni.

Ismert az a mondás, mely szerint a találmányok értéke azok megvalósíthatóságán keresztül mérhetô. Hál' istennek jó néhány kiváló magyar feltalálót és sikeres találmányt ismerïnk szerte a világban. Dr. Ladó professzor úr és canata egy ilyen találmányrendszort álltottuk össze és valósítottuk meg, ahol is a végzós hallgatók egyértelmúen bizonyíthatták és bizonyítják ma is a koncepció érvényességét. Így keletkezett az a valós hozzáadott érték, ami napjainkban talán ismét visszakapja feltétlen szükséges jelentését a gazdasági-pénzügyi folyamatokban. Nyugodt szívvel kijelenthetjü hogy dr. Ladó László professzor ur iskolát teremtet, amit mi is büszkén végeztünk el.

Az elsố és utolsó

\section{találkozás,}

és ami közte volt

Dr. Bálint Sándor vezérigazgató-helyettes, tulajdonos

évtized volt, amelyet e hosszú

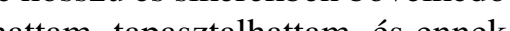
pályából közelról láthattam, tapasztalhattam, és ennek össze bennünket. Miután az életem más irányba terelt, össze bennünket. Miután az eletem más irányba terelt, nem szakadt meg a kapcsolatunk, szakmai, baráti, atyai keség tölt el ezt végiggondolva.

A szakmai, tudományos igényességú értékelés nem lehet az én tisztem, számomra az ember, aki mindeze mögött rejtôzködött, válik fontossá, egyre fontosabba
Az elsó találkozás

(A tanár úr, tanítónk fellép a katedrára)

1973 ốszén harmadéves gépészmérnök-hallgatóTanár Úrral.

A Múegyetem Audmax. termében, magas, szikár ember, katonás megjelenésével, egyenes szálfa tartásával, a még kissé zsibongó hallgatóság előtt kezdett bele mondandójába.

Bevallom, az elsố szavaknál még jobban figyeltünk az óraközi szünet fontos eseményeire, mint az ô szavaira. A figyelem iránytúje akkor kezdett más irányba fordulni, mikor a hangfoszlányokból kezdtük kihallani a változás, a reform, az új struktúrák, a bonyolult rendszerek, a komplexitás, a multidiszciplináris szavakat. Miról beszél? Mit mond? Ki ez az ember? Honnan jött? A Közgázról. Na nem, csak nem a PGtanszékrő́l? Nem. Onnan nem jöhetett, mert olyan mérnökien beszél. Nem ír fel egyetlen képletet sem, nincs a táblán differenciálegyenlet, nincsenek rajzok, mégis mérnöki. Szó van tervezésrốl, gyártásról, üzemeltetésról, karbantartásról, kutatásról. Beszél költségekről, bevételról, nyereségrốl, fedezetrôl - na ezek érdekes fogalmak, figyeljünk csak oda, ebból még kisülhet valami.

Így kezdődött, ezek voltak az elsố pillanatok, az első szavak, benyomások. Néhány évvel voltunk a Nyers Rezsố neve által fémjelzett új gazdasági mechanizmus és annak sajnálatos gyors elvetélése után. Ebben a politikai és gazdasági légkörben kellett elfogadtatni minisztériummal, egyetemmel azokat az új irányzatokat, amelyek a nyugati egyetemeken az industrial engineering, a mérnök management szakok példáját, tantárgyi struktúráját kívánták követni. Aki ott hallgatóként ült a teremben, nem tudhatta, hogy milyen csaták, milyen ütközetek elózték meg az új szak indítását. Miként fogadtatta el Ladó professzor az általa megtervezett, megszervezett és életre hívott új mérnöki kurzust, a termelési rendszer szakot.

A mérnöki pálya alapvetô sajátossága a természettudományos ismeretek szerteágazó, elmélyült, kreatív kalmazása olyan feladatok megoldására, amelyek z ember, az emberek hétköznapi életét teszik szebbé, jobbá, vagy éppen keserúvé, borzasztóvá. Mérnökök munkájának eredménye a ház, az autó, a kávéfőző, a televizio és még sok-sok kellemes és hasznos eszköz letünk könnyưvé, széppé tételében. Mérnökök alkották a fegyvereket is, a robbanóanyagot, mérnökök múve a környezetszennyezés nagy része, az egészségkárosító sugárzás és még sok más kellemetlen és káros dolog is. A mérnöki munka nem magányos tevékenység. Sokféle tudást, eszközt, szakembert kell mozgatni, 
mozgósítani, egy irányba terelni az eredmények meg születéséig. A tradicionális, természettudományos alapokon nyugvó mérnöki ismeretek mellett egyre inkább hangsúlyt kapnak a gazdasági, társadalomtudományi és humán ismeretek a mérnöki munkában is.

Aki figyelt, márpedig sokan figyeltek, valószínúleg csak valamikor jóval késóbb értették meg szavai fontosságát. Ha a megértésre még várni is kellett néhány évet, megérezni már akkor is lehetett, hogy aki mérnöki pályája során az összetett problémák multidiszciplináris megoldása irányábaérdeklődik annak itt a helye, ezszámára a mérnöki pálya izgalmakat, sikert hozó teriiete. Ez maradt meg számomra az elsó találkozás életre
szóló, meghatározó élményeként.

Kesổbb munkatársaként tanársegédként, maj adjunktusként módom nyílt arra, hogy tudományos és tanári pályája egészébe betekintést nyerhe sek, annak kicsiny mértékben részesévé válhassak. Ladó professzor tudományos munkásságában, a vezetési funkciók tanulmányozása és a vezetới tevékenységhez kapcsolódó módszerek tudományos igényességgel történő kidolgozása jelenik meg. A vezetési funkciók hármasából, tervezés, szervezés, ellenôrzés, két jelentôs bástya rajzolódik ki számomra az ő munkásságában:

- az iparvállalatok gazdaságtanának mélyreható elemzése,

- a szervezés elméleti és módszertan területén végzett munkássága.

A 60-as évek végének, a 70-es évek legelejének kiemelkedô, máig ható eredményeit munkatársaiva Deli Lászlóval és Kocsis Józseffel közösen publikált A Deli - Kocsis - Ladó hármas fémjelezte a komple iparvállalati tervezés módszertanának és a rendszereméleten alapuló gazdaságossági számítások alapjainak lerakását. Gyakorló mérnökök, vállalati vezetők sajátitották el előadásaik során, elsôsorban a posztgraduális képzés keretei között, ezeket az ismereteket. Az általuk e témákban megjelentetett könyvek féltve ôrzött példányai a szakma gyakorlóinak. Ez az a bástya ôt példá nyai a szakna gyakonónak. Ez az a bastya, amely támaszkodva a vezetés tervezési funkció jelentôs mér-
tékben alapozhatók. A 70-es évek második felében és a 80-as évek elején a vezetés szervezési funkciói számára végzett elévülhetetlen érdemekkel bíró kutatásokat, és publikálta azokat, máig meghatározó jelentőséggel bíró munkáiban. A Szervezéselmélet és módszertan kötet ennek zászlós hajója.

Ez a mú a tudományos kutatómunka összegzése és eger egyszerú ötvöz e két dolgot. Mégis meg kell állapítani, hogy a szerve- zés-módszertani fejezet, amely jelentốs mértékben új kutatási eredményeket foglal össze, tanítható és tanulató írás.

Sokan tették fel korábban a kérdést, lehet-e, szabad-e egyetemi hallgatóknak vezetési ismereteket oktatni, hiszen nincsenek tapasztalataik a vállalati rendszer múködéséról. Ladó professzor bebizonyította, hogy nemcsak hogy lehet, hanem egyenesen kötelezô is ezt megtenni, hiszen a mérnökök többsége rövid idốn belül vezető pozícióba kerül, és szüksége lesz ezekre az ismeretekre.

A szervezés módszertanának új alapokra helyezésével - a modellekre és résztechnikákra - épüló koncepció kialakításával a magyar szervezési iskola olyan alappillérét dolgozta ki, amely lehetôséget nyitott e tudományterület elsajátításának és alkalmazásának egy đjj útja felé.

Keretrendszert hozott létre, meglévő és új szervezetek szervezési feladatainak megkülönböztetésével. E keretrendszert fogalmazta meg modellek formájában. A modellek, mint egy épület vázszerkezete, adják a lehetőséget arra, hogy az eltérô sajátosságokkal bíró feladatokhoz adekvát megvalósítási technikákat, résztechnikákat kiválasztva építôszekrény elv szerint alakuljon egy-egy szervezési feladat valós képe. Tudományos munássátét látsź́lagos kettósśs képe. 作 mezte. Vegten szorgalonno tudoskén in , nagyobb csapatot épített maga köré és instruálta, ambicionálta kollégáit egy-egy téma feldolgozására, amelyet azután szintetizált munkáiba. Irányította, pallérozta a körülötte dolgozó fiatalabb és idősebb kollégákat. Megteremtette annak a lehetôségét, hogy akiben pislákolt az ambícióparazsa,azazôsegítségévellángralobbanthassa. Ennek a szervező, nevelő munkának egyik legpregnánsabb megjelenése a „Szervezettség, hatékonyság" könyvsorozat, amely sok, akkor fiatal kutató és szakember számára nyitott utat a szervezési iskolába való feliratkozásra. Sokan a sorozat szerzői közzil ma emblematikus figura

\section{Ellenórzés}

A nyolcvanas évek elején jelentette meg a vezetés ellenőrzési funkcióinak egyik aspektusát feldolgozó munkáját, a Teljesítmények és ráfordítások (1981) címú könyvét. Ennek a múnek a „Tervezés, mérés, értékelés" alcímet adta. A szervezési kutatásait követóen visszakanyarodik korábbi jelentôs eredményeket hozó, és valljuk be, máig egyik legsikeresebb kutatási témájához, a rendszerszemléletư gazdaságossági számításokhoz. Ebben a munkában jelenik meg az a nevén nevezett kontrollingszemlélet és módszertani eljárás, amely napjainkban is sok vállalat számár jelenti a terv-tény összehasonlítás, értékelés alapjait. Felteszem a kérdést: Hol hasznosulhat ennek a munkásságnak a gyümölcse, hogyan hasznosulhatna jobba mai magyar valóságunkban? Van-e helye az elmúlt évtizedekben a sajátos magyar vezetési szervezési iskola által produkált intellektuálisan és gyakorlatiasságába is kimagasló eredményeknek a ma vállalati rendsze reiben?

A válaszom IGEN, van helye, nagyon is jól definiálható ez a hely. A rendszerváltás óta Magyarországra beköltözött multinacionális cégek hozták, hozzák sajátos sablonjaikat, nem hagyva helyet sem önállóságnak, sem sajátos módosításoknak, ami a szervezeti múködés rendjét illeti. Ezt a szférát nem igazán tekinthetjük jó talajnak.

A középvállalatok, a kisvállalatok, amelyek nem determináltak valamely nagy mamut szabályai által, azok számára alkotó energiát szolgáltathatnak mindazok az ismeretek, tudományos eredmények, amelyek ebben az életmúben fellelhetók. Ezrével, tízezrével léteznek ezek a szervezetek, amelyekhez el lehet, el kell juttatni Ladó László professzor és a Magyar Szervezési Iskola többi kiemelkedő alakjának tudományos eredményeit. Jómagam több mint másfél évtizeden keresztül láthattam, követhettem nyomon a kutató, az oktató, a neveló tanár munkáját. Miután utam más irányba terelt, sem szakadt meg a közvetlen kapcsolat, a szakmai kontaktus, az atyai barát, gondoskodó, terelgetô segítsége.

\section{Az utolsó találkozás}

az elmúlt év nyarára datálódik

(Beszélgetés iskoláról, munkáról, tervekról,

számvetésról)

Nyugdíjaséveiben is gyakoriak voltak találkozásaink. Mi tanítványai, évente néhány alkalommal kerestük a lehetôségét, hogy meghallgassuk véleményét szakmáról, munkáról, a világ dolgairól. Utolsó találkozásunk egyik témája a tanítás, a nevelés kérdése volt. A Pozsonyi úti ház bejárata elốtt, a búcsúzást megelốA Pozsonyi ût ház bejárata elón, a búcsúzást megeló-

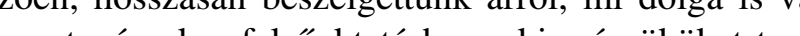
egy tanárnak a felsôoktatásban, aki ménôkôket tan nevel. Mennyire változott az elmúlt két-három évtizedben az egyetemi oktato szerepe, lehetóségei, feladata Soknak kell-e tekinteni két-három évtized múlását nevelói szerepben? Érdekes és nagyon tanulságos gondolatokat fogalmazott meg mindezekról.

„Tudod, Sanyikam, mikor kiállsz a katedrára kê dolog mindig legyen nálad. A vázlataid, amelyekkel

az elóadásra készültél, mert felkészületlenül soha nem léphetsz be a tanterem ajtaján. Tiszteletlenség és felelốtlenség fiatal emberekel szemben, ha nem a legjavát akarod adni tudásodnak.

A másik fontos dolog, ami belóled jön. Vidd magaddal emberséged! Vidd az előadásra, vidd a vizsgara, hasson át az a hit, hogy jó szándékú, tanulni vágyó, tudásra szomjazó mérnökpalánták várnak a padsorokban! Ez igaz volt ötven évvel elốtte is, és igaz ma is. Mindegy, hogy mi az aktuális tananyag."

A kapu becsukódott, és nem láttuk többé egymást. Örzöm a tóle kapott útravalót. Nincs más dolgom, mint megórizni és továbbadni.

\section{Alapítvány}

Hogyan? Mi módon lehet továbbvinni az eredményeket, az átadott stafétabotot? A ma hallgatósága, a fiatal kutatók, a kezdố szakemberek az a talaj, ahol a magot el kell vetni. Nekünk, kiknek megadatott, hogy közvetlenül tôle tanulhattunk, hogy ő irányított minket, ránk hárul a felelösség és kötelesség. Szeretném bejelenteni, hogy bejegyzésre került egy alapítvány, a „Dr. Ladó László Alapítvány”, amelynek célja, hogy segítse az ó́lttala teremtett tudomá-

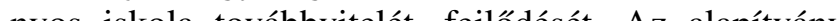
nélu irzte ki, hogy segit, cét ténte ki, hogy segth, tánogatja, jutalmazza azoladva ladva tanulmányaikban, tudományos kutatásaikban eredményesen teljesitenek. Elismerést kíván adni az alapítvány azoknak a tanároknak is, akik a fiatalokat irányítják, tanulmányaikban utat mutatnak nekik. Kérem a tisztelt hallgatóságot, hogy segítsék az alapítvány munkáját ebbéli törekvésében.

Perlaki Jenó,

\section{volt polgármester} országgyúlési képvisel

vábbá az Oöszággyúi Ǵláśn ák szab́lyozáś́t említette, mint olyan felar tot, ahol támaszkodott Ladó László és munkatársainak módszertanára.

„Polgármesteri székfoglalómban azt ígértem, hogy a modern szervezéstudomány eredményeinek segítségéve fogok dolgozni. És valóban! A polgármesteri hivatal és a kerület életének szervezése során fel kellett használni a szervezési ismereteket. Késóbb az lett a feladatom, hogy a közbeszerzési törvénnyel foglalkozzak az Országgyứ 
lésben. Felhívtam Kindler professzor úrat, aki azt mondta, hogy szerinte Magyarország még nem érett a pontrendszer alkalmazására. Ehhez képest, mire a törvény hatályba lépett, akkorra már a kijátszására is megszülettek a megoldások a gazdaság szereplőinek körében, amelyeket most nem fogok felsorolni." (A hallgatóság számára nyilvánvaló volt, hogy a hozzászóló a professzor tanítványa és a pontrendszerre épülő KI-PA döntési módszer egyik megalkotója a jelen lévő Kindler professzor.)

\section{Dr. Stépán Gábor, akadémikus, a BME}

A dékán úr hangsúlyozta, hogy Ladó proGépészmérnöki Kar dékánja szeretnék megőrizni, mint az Egyetem többi nagy tanáregyéniségéét. Megköszönte a jelenlévő, számos intézményt és szakmát képviselő közösségnek, hogy ebben a kezdeményezó szerepet felvállalta. Személyes érintettségét hangsúlyozandó felelevenítette gyermekkori emlékét, amikor édesapja révén Ladó professzor optimalizálási eljárásaival találkozott.

\section{Elnöki zárszó}

Dr. Barakonyi Károly, az MTA VSZB elnöke, a PTE professor Emeritusa
Ladó professzor olyan sokoldalú, színes egyéniség volt, akinek nehéz néhány szóban összefoglalni az életútját. Maga a könyv is több perspektívában tünteti fel ốt. Bölcsességét pedig mi sem bizonyítja jobban, minthogy bármilyenek is voltak a körülmények, mindig képes volt értő és elôrevivő, akár ma is vállalható javaslatokkal elóállni. Arisztotelészt idézve: „a közösség alapja a vonzódás”. Úgy látja, hogy bizonyos fokig távolságtartó személyisége ellenére Ladó professzor olyan vonzerốt tudott kifejteni, amely valódi közösséget teremtett munkatársai és tanítványai körében. Az elnök úr végül megköszönte az elsố számú szervezô, Erdôsi Gyula fáradhatatlan munkáját és áldozatvállalását az emlékülés elốkészítésében, illetve a Ladó László-emlékkönyv és CD megjelentetésében.

\section{Dr. Erdósi Gyula, az emlékkönyv és a CD szerkesztốje}

Miután az emlékülés tagjainak kiosztották a Ladó László-emlékkönyvet és iskolájáról készült $\mathrm{CD}$ tiszteletpéldányait, Erdôsi Gyula röviden ismertette e múvek tartalmát, illetve megszületésük körülményeit. Ezt követően szót ejtett arról az alapítványról is, amit Bálint Sándor, az elnök jelentett be, amely Ladó László professzor nevét fogja viselni, és küldetése a jövố tudósgenerációjának támogatása a vezetés- és szervezéstudomány területén. Végül a közösség tagjait meginvitálta a második emeleti körfolyosón, a Ladó professzor tiszteletére rendezett állófogadásra. 